\title{
QUALITY ASPECTS OF IMPROVING THE PRODUCTION PROCESS EFFECTIVENESS BY ELIMINATING CRITICAL DEFECTS
}

\author{
Bożena SKOTNICKA-ZASADZIEŃ \\ Silesian University of Technology, Faculty of Organization and Management, Institute of Economics and \\ Informatics; bozena.skotnicka@polsl.pl, ORCID: 0000-0003-1717-304X
}

Purpose: Critical defects are of great significance when evaluating the production process effectiveness, especially in the automotive branch. It is important to analyse these defects and distinguish the crucial ones. In this article, the authors have identified critical defects in the process of brake master cylinders production using quality management tools, and proposed improvement actions.

Design/methodology/approach: The aim of the article was to analyse defects and the reasons for their occurrence, and improve the production process of master cylinder with special attention to critical defects.

In order to improve this process, critical flaws had to be identified and eliminated from the entire set, which was the engineering problem to be solved. Then the causes of their occurrence as well as the factors causing process disturbances affecting the final occurrence of the defect were identified, and actions eliminating or limiting their occurrence were proposed. In the project, they were used to analyse the tools and principles, i.e. process diagram, Pareto-Lorenz diagram, cause-effect diagram, and to improve the Poka-Yoke process.

Findings: Based on the examined causes of defects, improvements were proposed, i.e. guides for applying the body, a program stopping the piston assembly station to control the oil level, purchase of caps from sealed material and the need to work in long-sleeved work clothing, moving the body type verification camera from the final to first station, pallet spacers to protect against piston damage, change of supplier, especially of body castings.

Research limitations/implications: The major limitation of the paper is that it is based on one case of an organization. In the future, it will be necessary to conduct studies in more organizations so as to find out if the same result can be achieved.

Originality/value: Until now, no quality management tools have been used to analyse and organize the formation of defects in production processes.

Keywords: improvement, critical defects, production process, automotive branch, quality management tools.

Category of the paper: Research paper. 


\section{Introduction}

In a modern organisation it is impossible to close the working cycle by merely controlling particular processes, as this will not show the actions following the inspection. The role of continuous improvement is to undertake corrective and preventive actions, but also to draw conclusions from data analysis (Antosz, Pacana, Stadnicka, 2015; Zasadzień, Wolniak, Skotnicka-Zasadzień, 2017). Careful examination of the collected data about production processes enables corrections and changes to be made. The level of quality should be increased by improving external quality, which allows the enterprise to obtain better products, while maintaining their customer service on a possibly high level, which results in customers' greater satisfaction, and an increasing share in the market for the enterprise, finally leading to profit maximization (Gruszka, Ligarski, 2017). These improvements should be made by improving external quality, which allows for greater efficiency as well as the optimization and rationalization of process management, which, in turn, will result in a lower number of mistakes, and, in consequence, lower costs accompanied by higher profits (Luczak, MatuszakFlejszman, 2007; Zasadzień, 2017). Continuous improvement should concern all employees and processes, which means that it ought to include the whole organization. The employees should be made aware of improvement possibilities and motivated accordingly (Milewska, Kossowska, 2017; Molenda, 2016). Such an approach in the long term will pay off, as, for example, financing an award for an operator will be a lower cost than potential complaints, which could be prevented by the proposed improvements (Pacana, Stadnicka, 2015; Skotnicka-Zasadzień, Wolniak, Gembalska-Kwiecien, 2018). Improvements are made not only at the stage of manufacture - certain actions are undertaken already in the initial stages of the process, e.g. planning, and continue until the product leaves the factory, sometimes even longer, enabling the enterprise to maximize its profits and gain prestige. An important role in production process improvement is played by analysis and elimination of defects, which may appear in the process of product manufacture (Zasadzień, 2017). The analysis of the causes of defects and their identification can be supported by quality management tools and methods (Stadnicka, 2016; Zasadzień, 2016; Wolniak, Skotnicka, 2011). In this article, the improvement of the process of brake master cylinders production has been presented by identifying critical defects in the production process and implementing the improvement actions. The subject of research were automotive branch enterprises (Posmyk, 2018). 


\section{Research problem analysis}

Defects of brake master cylinders are most frequently detected at the assembly stage by operators or testing stations, but sometimes systems fail and a defective product is sent to the customer, which results in a complaint. There are also situations when a manufactured product is nonconforming, as the components delivered by the supplier are damaged, which can only be proved in detailed quality analyses or microscopic investigations. Table 1 presents the quantity and ratio of all the defects to the total volume of production (Posmyk, 2018).

Table 1.

Number of all the defects in relation to the whole production volume

\begin{tabular}{|c|c|c|}
\hline Year & Number of defects (pcs) & \% share in total production volume \\
\hline 2013 & 32,494 & 0.70 \\
\hline 2014 & 40,084 & 0.77 \\
\hline 2015 & 49,735 & 0.82 \\
\hline 2016 & 66,337 & 0.97 \\
\hline
\end{tabular}

Source: Posmyk, 2018: Analiza i ograniczenia powstawania wad w procesie produkcyjnym pomp hamulcowych, Zabrze.

\subsection{Defects detected in the production process and at the customer's}

Defects that occur in the process of brake master cylinders production can be divided into unidentified defects which resulted in the customer's complaint and defects that were detected at the stage of assembly. The number of defects identified in the production process by operators and testing stations in particular years as well as their number in relation to particular defect groups have been given in Table 2 .

Table 2.

Number of critical defects at the assembly stage detected by operators and testing stations

\begin{tabular}{|c|c|c|c|}
\hline Year & Quantity [pcs] & Defects in the years 2013-2016 & Quantity [pcs] \\
\hline 2013 & 31,280 & leakage - contaminations & 148,360 \\
\hline 2014 & 39,010 & damaged material & 22,254 \\
\hline 2015 & 49,200 & mixed-up material & 12,982 \\
\hline 2016 & 65,960 & dimensions out of tolerance & 1,854 \\
\hline
\end{tabular}

Source: Posmyk, 2018: Analiza i ograniczenia powstawania wad w procesie produkcyjnym pomp hamulcowych, Zabrze.

The article is mainly focused on defects undetected during the production process, as these areas should be the first to improve. Table 3 presents grouped defects that have been identified at the customer's premises. 
Table 3.

Grouped defects identified by the customer in particular years

\begin{tabular}{|c|c|c|c|}
\hline Year & Defect & $\begin{array}{c}\text { Number of complaints } \\
\text { [pcs] }\end{array}$ & $\begin{array}{c}\text { Number of complaints } \\
\text { [pcs] }\end{array}$ \\
\hline 2013 & liquid leakage-contamination, damage & 5 & 5 \\
\hline 2013 & no functionality - soft brake pedal & 2 & 2 \\
\hline 2013 & incomplete product & 2 & 2 \\
\hline 2013 & no possibility of screwing brake lines & 1 & 1 \\
\hline 2013 & damaged piston & 1 & 7 \\
\hline 2014 & liquid leakage - contamination, damage & 4 & 4 \\
\hline 2014 & nonconformity of order number & 2 & 2 \\
\hline 2014 & no functionality - soft brake pedal & 1 & 1 \\
\hline 2014 & nonconformity of model order & 7 & 7 \\
\hline 2014 & damaged piston & 2 & 2 \\
\hline 2015 & liquid leakage - contamination, damage & 1 & 1 \\
\hline 2015 & incomplete product & 10 & 11 \\
\hline 2015 & no functionality - soft brake pedal & 2 & 3 \\
\hline 2016 & liquid leakage - contamination, damage & 2 & 2 \\
\hline 2016 & incomplete product & 7 & \\
\hline 2016 & nonconformity of product order & 7 & \\
\hline
\end{tabular}

Source: Posmyk, 2018: Analiza i ograniczenia powstawania wad w procesie produkcyjnym pomp hamulcowych, Zabrze.

\subsection{Identification of critical defects}

Table 4 presents defects detected in the production process by testing stations and the ones reported by operators, defects revealed in control tests carried out by the quality control department, as well as complaints received from the customers. Based on the data, a Pareto chart has been prepared.

Table 4.

List of critical defects of brake master cylinders

\begin{tabular}{|c|c|c|c|c|c|}
\hline No. & Description of defect & $\begin{array}{c}\text { Number of } \\
\text { defects }\end{array}$ & Share [\%] & $\begin{array}{c}\text { Cumulative share } \\
{[\%]}\end{array}$ & group ABC \\
\hline 1. & metal contamination & 103,118 & 54.661 & 54.661 & $\mathrm{~A}$ \\
\hline 2. & rubber contamination & 30,923 & 16.392 & 71.053 & $\mathrm{~A}$ \\
\hline 3. & remaining contaminations & 17,481 & 9.266 & 80.319 & $\mathrm{~B}$ \\
\hline 4, & mixed-up component & 12,342 & 6.542 & 86.861 & $\mathrm{~B}$ \\
\hline 5. & damaged pistons & 12,127 & 6.428 & 93.290 & $\mathrm{~B}$ \\
\hline 6. & damaged gaskets & 5,612 & 2.975 & 96.264 & $\mathrm{C}$ \\
\hline 7. & material rust & 2,452 & 1.300 & 97.564 & $\mathrm{C}$ \\
\hline 8. & dimensions out of tolerance & 1,828 & 0.969 & 98.533 & $\mathrm{C}$ \\
\hline 9. & damaged grommets & 1,531 & 0812 & 99.345 & $\mathrm{C}$ \\
\hline 10. & gasket missing & 584 & 0.310 & 99.654 & $\mathrm{C}$ \\
\hline 11. & rolled-up gasket & 547 & 0.290 & 99.944 & $\mathrm{C}$ \\
\hline 12. & extra gasket & 51 & 0.027 & 99.971 & $\mathrm{C}$ \\
\hline 13. & deformation of ports & 28 & 0.015 & 99.986 & $\mathrm{C}$ \\
\hline 14. & spring grips missing & 11 & 0.006 & 99.992 & $\mathrm{C}$ \\
\hline 15. & springs missing & 6 & 0.003 & 99.995 & $\mathrm{C}$ \\
\hline 16. & packaging without product & 4 & 0.002 & 99.997 & $\mathrm{C}$ \\
\hline 17. & mixed-up label & 2 & 0.001 & 99.999 & $\mathrm{C}$ \\
\hline 18. & porosity & 2 & 0.001 & 99.999 & $\mathrm{C}$ \\
\hline 19. & incorrect pump model & 1 & 0.001 & 100.00 & $\mathrm{C}$ \\
\hline
\end{tabular}

Source: Posmyk, 2018: Analiza i ograniczenia powstawania wad w procesie produkcyjnym pomp hamulcowych, Zabrze. 


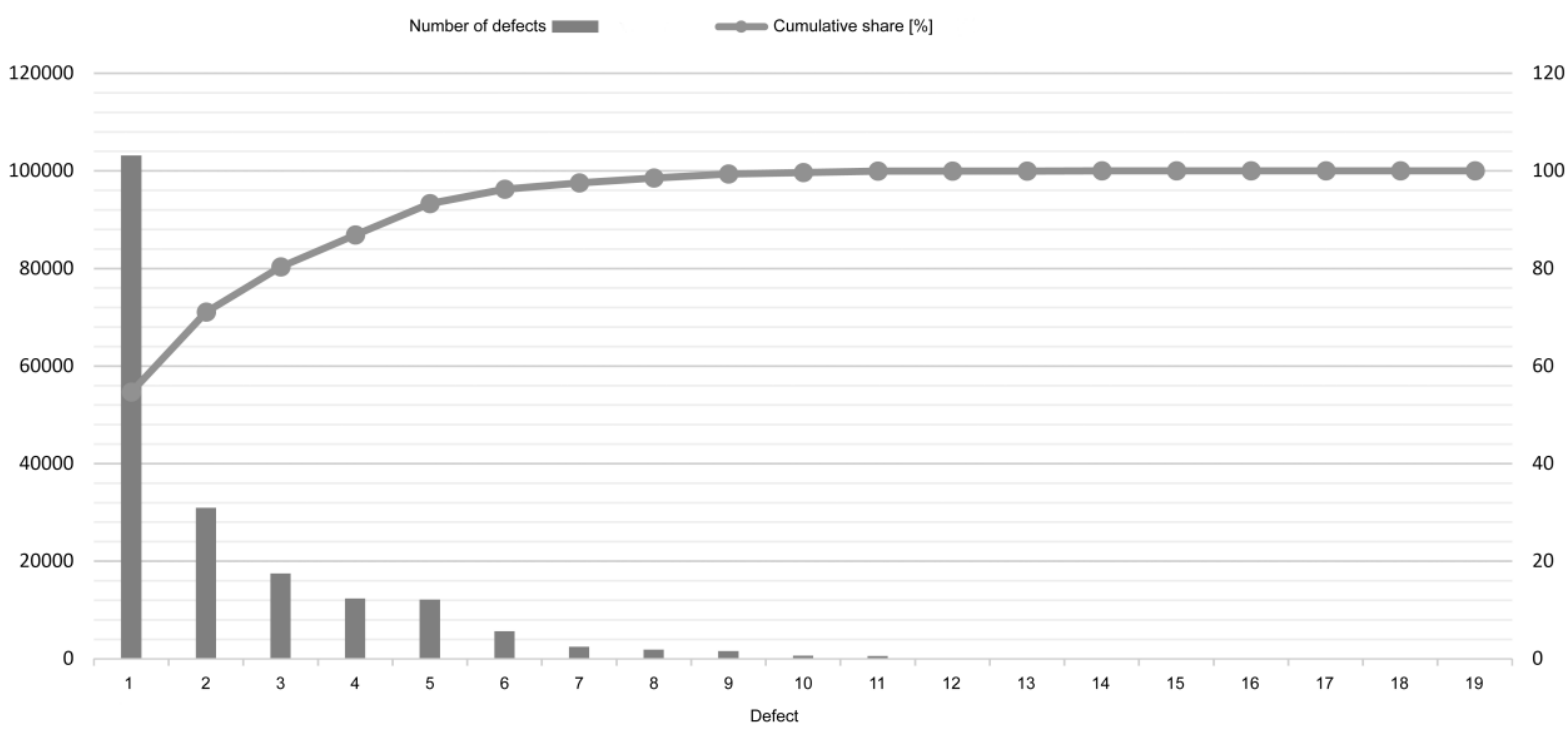

Figure 1. Pareto-Lorenz diagram. Source: Posmyk, 2018: Analiza i ograniczenia powstawania wad w procesie produkcyjnym pomp hamulcowych, Zabrze.

\subsection{Causes of critical defects}

An analysis of the causes of metal contaminations has been presented in Fig. 2. An equally important defect - improperly installed material, analysed in terms of its causes has been presented in Fig. 3. A less common, but equally important problem of piston damage has been analysed in Fig. 4.

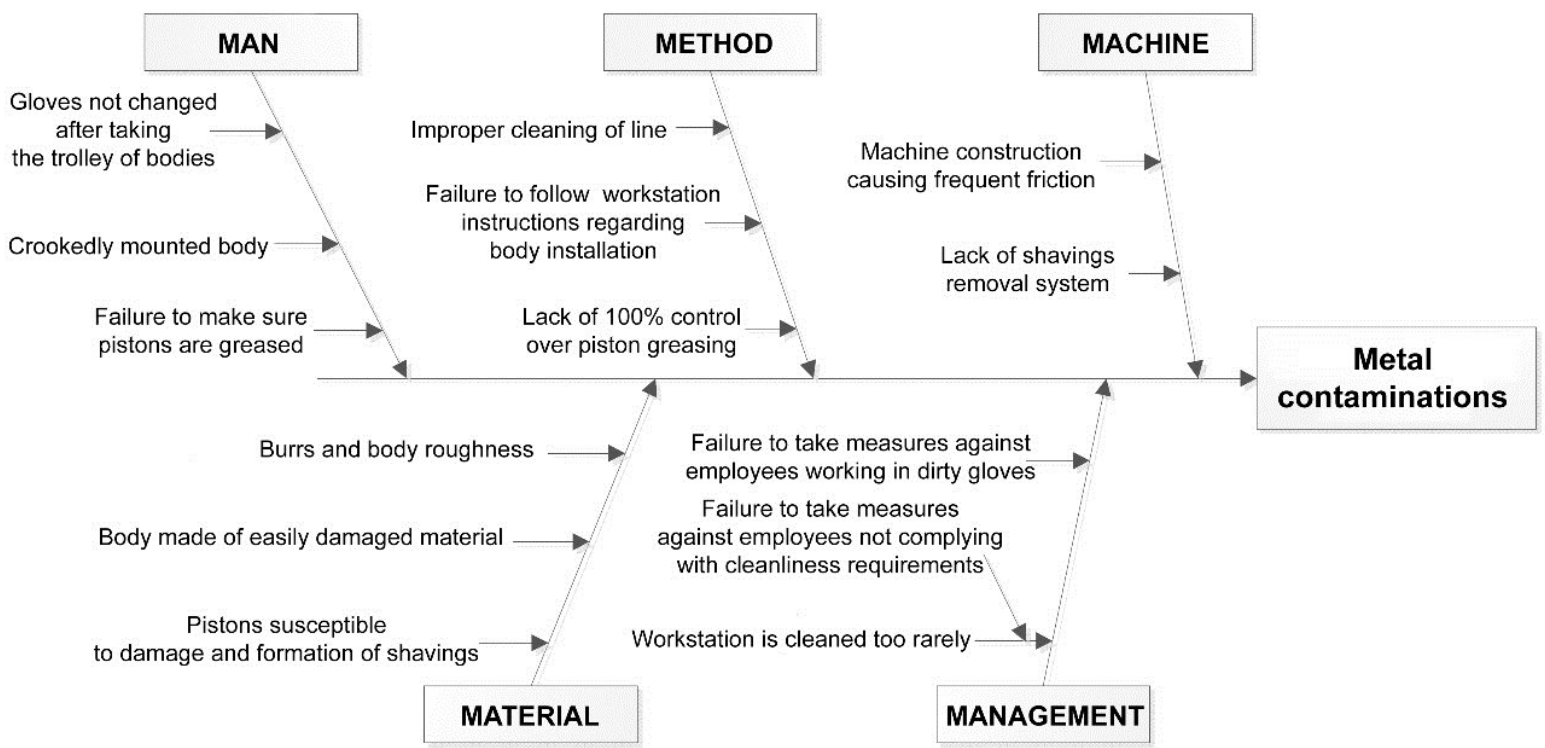

Figure 2. Ishikawa diagram for metal contaminations. Source: Posmyk, 2018: Analiza i ograniczenia powstawania wad w procesie produkcyjnym pomp hamulcowych, Zabrze. 


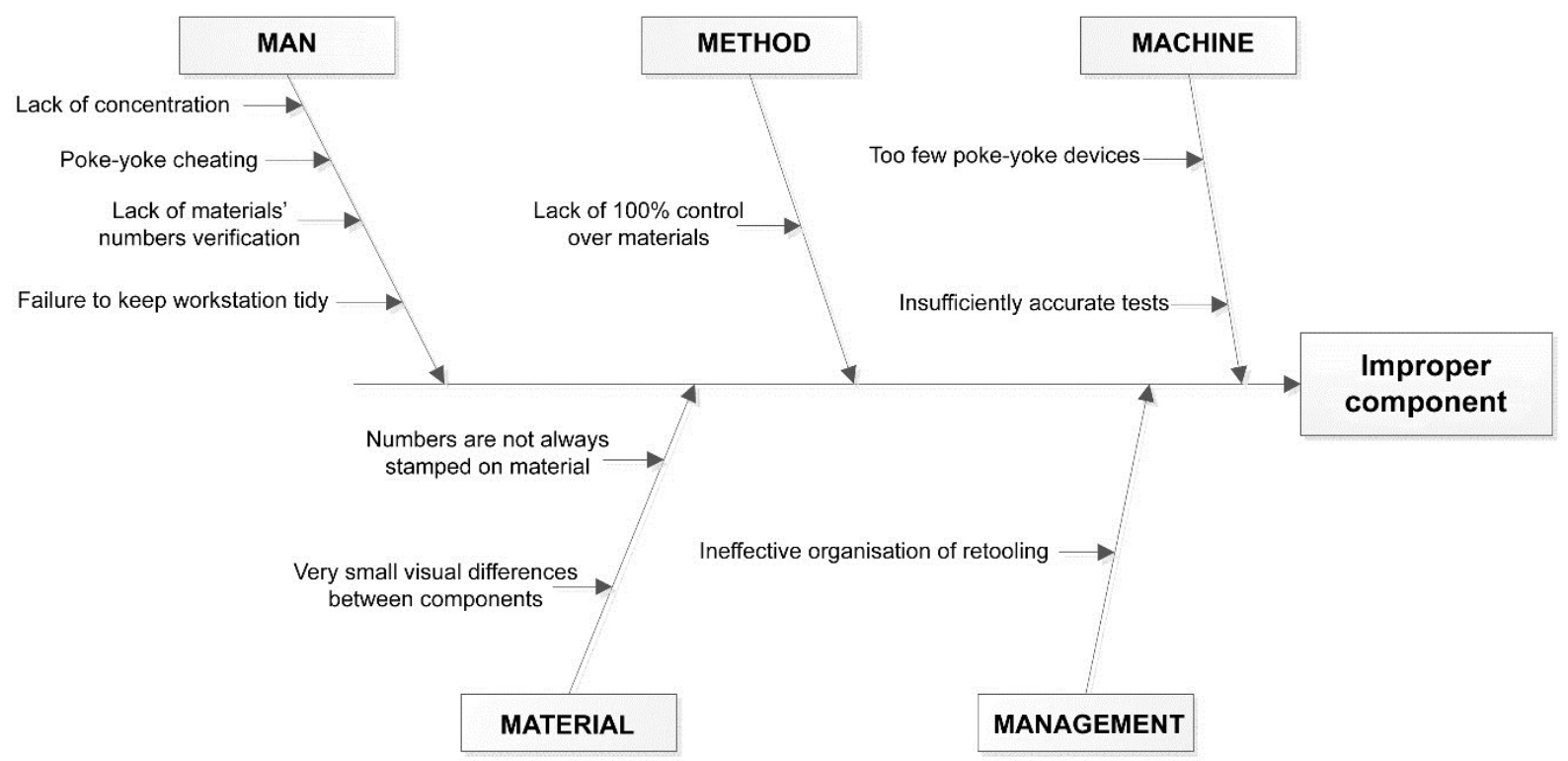

Figure 3. Ishikawa diagram for improperly mounted components. Source: Posmyk, 2018: Analiza i ograniczenia powstawania wad w procesie produkcyjnym pomp hamulcowych, Zabrze.

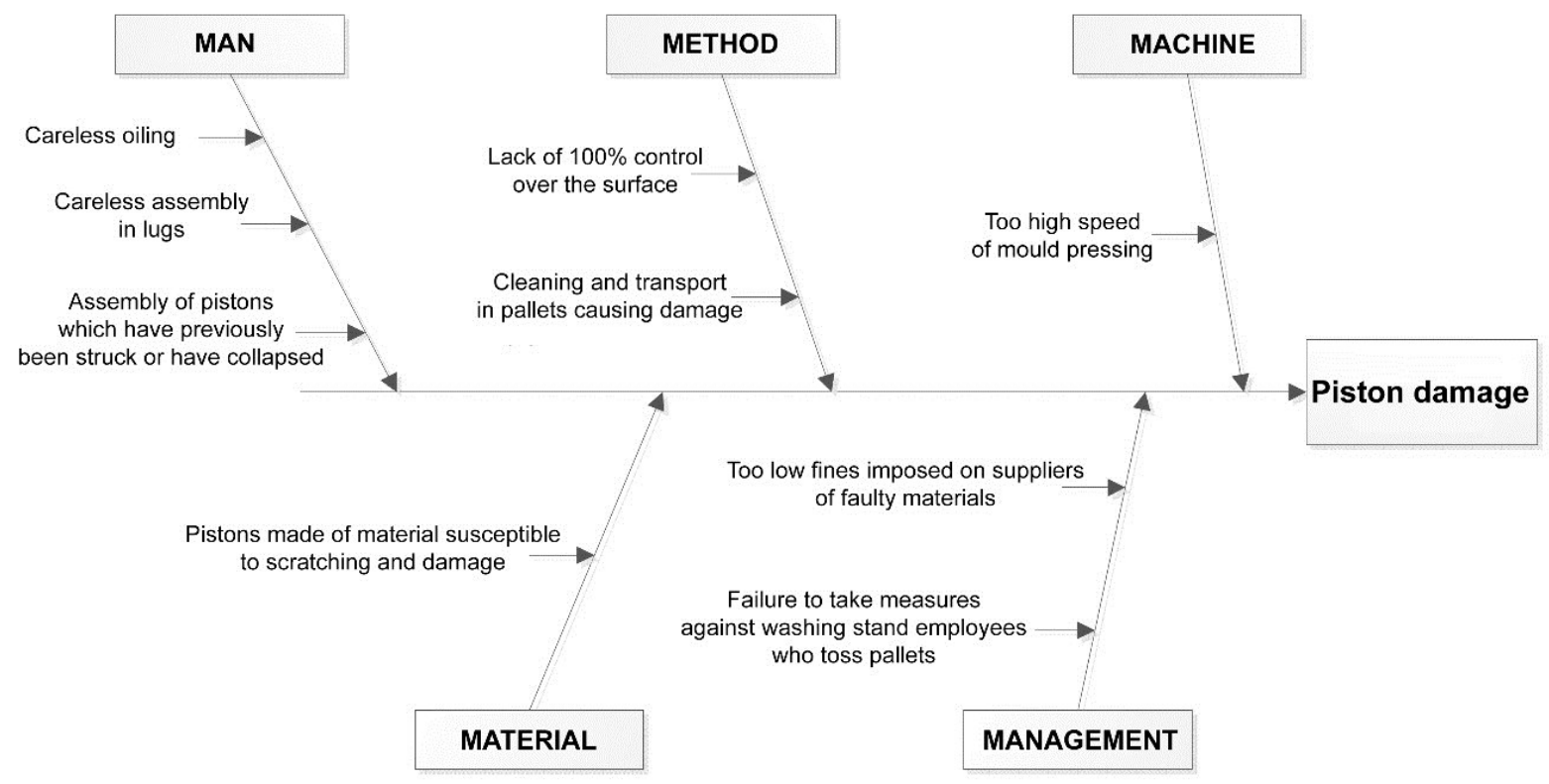

Figure 4. Ishikawa diagram for damaged pistons. Source: Posmyk, 2018: Analiza i ograniczenia powstawania wad w procesie produkcyjnym pomp hamulcowych, Zabrze.

\section{Improvement actions}

After the conducted analysis of critical defects, improvement actions were proposed, the aim of which was to limit and eliminate key critical defects. Elimination of key critical defects will result in lower production costs and a reduced number of complaints from customers (Posmyk A. 2018). 


\subsection{Elimination of critical defects}

The first critical defect with regard to quantity is brake master cylinder contamination with metals. To minimize this kind of defect, it has been proposed to install guide bars for placing the body onto the mounting device, which will force its axial installation and, in consequence, will eliminate the shavings, which are currently produced due to angular installation, as presented in Fig. 5. If they reach a gasket, shavings most frequently cause it to leak; this, in turn, results in brake fluid leakage, which is the most frequent cause of customers' complaints, entailing very high quality costs (Posmyk A.2018).

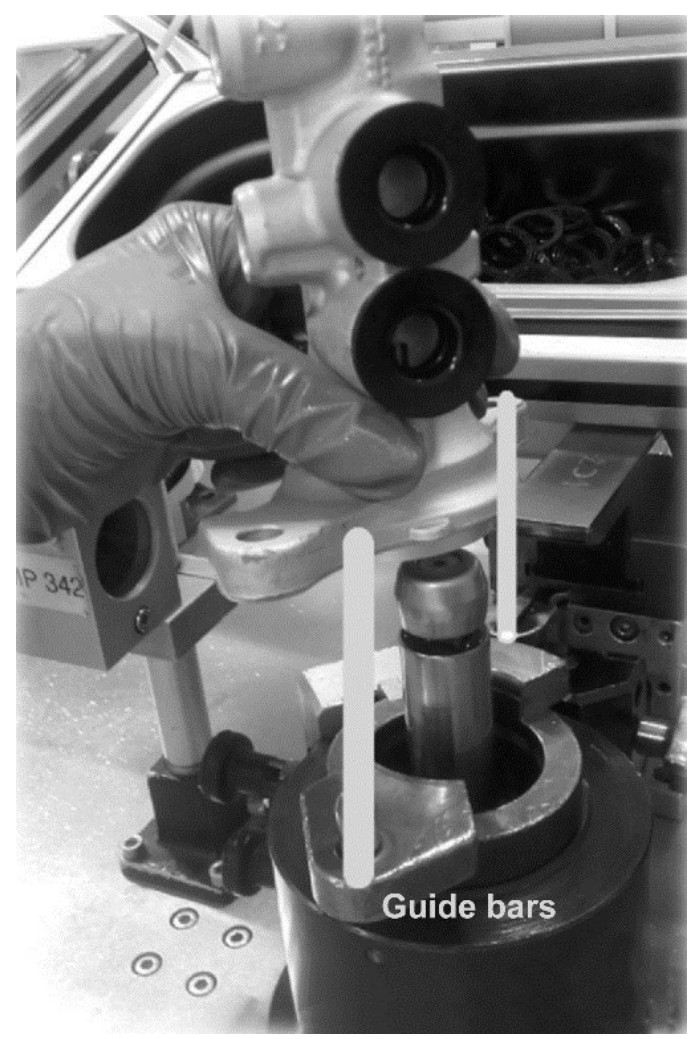

Figure 5. Incorrect angular installation of the body. Source: Posmyk, 2018: Analiza i ograniczenia powstawania wad w procesie produkcyjnym pomp hamulcowych, Zabrze.

The problem of shavings can also be minimised at the station of pistons installation. Operators do not pay attention to their proper greasing, which leads to the production of metal filings when the piston is mounted by means of an actuator on the body, which causes friction. It can also cause damage of the previously mounted gaskets. The proposed solution to this problem is using a programme which stops the mounting station after each $50^{\text {th }}$ greased piston and requires the topping up of oil to be confirmed. A message appearing on the panel will play the role of a reminder, which will increase the chances of the operator taking notice of whether the sponges have been properly soaked. Visualization of the described Pola-Yoke has been presented in Fig. 6. 


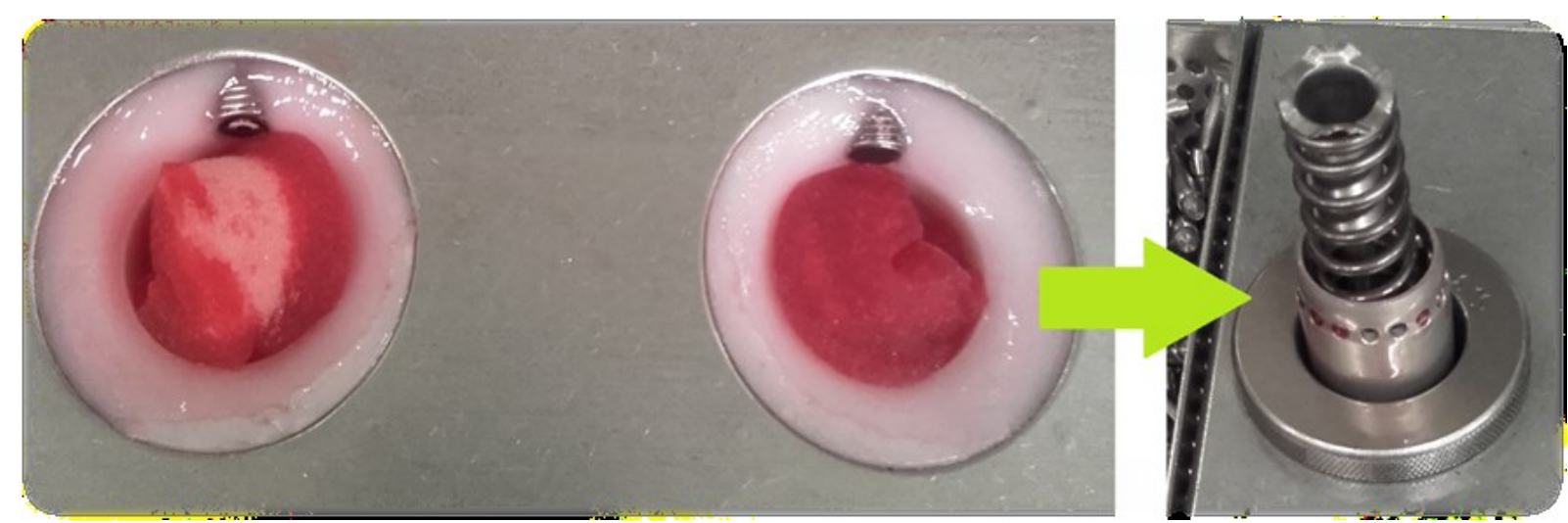

Figure 6. Sponges properly soaked with oil and a properly greased piston. Source: Posmyk, 2018: Analiza i ograniczenia powstawania wad w procesie produkcyjnym pomp hamulcowych, Zabrze.

In the case of contaminations with rubber, i.e. a material that may come from both torn gloves and damaged gaskets, disciplinary measures should be taken against both operators who work in damaged gloves as well as those who do not keep their workstations tidy (Posmyk, 2018.

\section{Summary}

An analysis based on the information provided by the production plant allowed for determining critical defects from among the data, i.e. the number of defects reported by operators and detected by the testing stations, tests carried out by the quality control department as well as major defects in terms of costs and lack of detection, and customers' complaints. All the defects were classified into groups A, B or C. Improvement actions were focused on the first two groups, taking into consideration the examined causes of these defects, so that they can be eliminated at their source. They will enable reducing the number of defects, and, in consequence, costs incurred by the enterprise. Based on the conducted analysis, it can be stated that most of the complaints received by the enterprise from its customers were related to brake fluid leakage, caused by damage to materials or contaminations. Furthermore, an analysis of quality control tests revealed that approximately $50 \%$ of brake master cylinder contaminations were metals. Critical defects in group A include, respectively: metal contaminations (55\%) and rubber contaminations (16\%) (Posmyk, 2018).

Based on the analysis of defect causes, the following improvement actions were proposed: the use of guide bars for body installation, introducing a programme for stopping the piston mounting station to control the oil level, purchase of caps made of tight materials as well as the requirement to work in working clothes with long sleeves, transferring the camera for verifying the body type from the final to the first station, change of suppliers, especially the supplier of body castings. 


\section{References}

1. Antosz, K., Pacana, A., Stadnicka, D., Zielecki, W. (2015). Lean Manufacturing. Doskonalenie produkcji, Rzeszów: Oficyna Wydawnicza Politechniki Rzeszowskiej.

2. Gruszka, S., Ligarski, M. (2017). Ocena efektywności procesu produkcyjnego na przykładzie producenta złączy stalowych. Syst. Wspomag. Inż. Prod., 6, 6, p. 102-109.

3. Łuczak, J., Matuszak-Flejszman, A. (2007). Metody i techniki zarzadzania jakościa. Kompendium wiedzy, Poznań: Quality Progress.

4. Milewska, E., Kossowska, K. (2017). Use of work station performance indicator rating in the manufacturing processes improving. Syst. Wspomag. Inż. Prod., 6, 4, p. 130-139.

5. Molenda, M. (2016) Zasady ustalania mierników procesów w systemie zarządzania jakością. In: E. Milewska (ed.), System wspomagania $w$ inżynierii produkcji, 2(14), Gliwice: Wydawnictwo P.A. NOVA, p. 249-257.

6. Pacana, A., Stadnicka, D. (2015). Budowa i rozwój skutecznych systemów zarzadzania jakością. Rzeszów: Wydawnictwo Politechnik Rzeszowskiej.

7. Posmyk, A. (2018). Analiza i ograniczenia powstawania wad w procesie produkcyjnym pomp hamulcowych, Zabrze.

8. Skotnicka-Zasadzień, B., Wolniak, R., Gembalska-Kwiecień, A. (2018). Improving the efficiency of the production process using SMED. 12th International Conference Quality Production Improvement - QPI 2018, Zaborze near Myszków, Poland, June 18-20, 2018, R. Ulewicz and B. Hadzima (eds.). Les Ulis: EDP Sciences.

9. Stadnicka, D. (2016). Wybrane metody i narzędzia doskonalenia procesów $w$ praktyce, Oficyna. Rzeszów: Politechnika Rzeszowska.

10. Wolniak, R., Skotnicka, B. (2011). Metody i narzędzia zarzadzania jakościa. Gliwice: Wydawnictwo Politechniki Śląskiej.

11. Zasadzień, M. (2016). Metoda 5 Why jako element zarządzania eksploatacją w kopalni węgla kamiennego - próba implementacji. Syst. Wspomag. Inż. Prod., 1, p. 457-464.

12. Zasadzień, M. (2017). Application of the Six Sigma method for improving maintenance processes - case study. 6th International Conference on Operations Research and Enterprise Systems. ICORES 2017, Porto, Portugal, 23-25 February, 2017. SciTePress - Science and Technology Publications, p. 314-320.

13. Zasadzień, M. (2017). Six Sigma methodology as a road to intelligent maintenance. Prod. Eng. Arch., 15, p. 45-48.

14. Zasadzień, M., Wolniak, R., Skotnicka-Zasadzień, B. (2017). Doskonalenie procesu produkcji worków foliowych przy wykorzystaniu wybranych metod i narzędzi inżynierii jakości. Syst. Wspomag. Inż. Prod., 6, 8, p. 37-48. 